\title{
Legg-Calvé-Perthes hastalığı
}

\author{
Legg-Calvé-Perthes disease
}

\author{
Timur Yıldırım, Evren Akpınar
}

\section{S. B. Metin Sabancı Baltalimanı Kemik Hastalıkları Eğitim ve Araştırma Hastanesi, İstanbul}

Legg-Calvé-Perthes hastalığı tanımlanmasının üzerinden bir asır geçmiş olmasına rağmen gerek etiyolojisinin tam olarak aydınlatılamamış olması gerekse tedavisi üzerinde fikir birliğinin oluşmaması nedeniyle gizemini halen korumaktadır. Perthes hastalığı femur başı epifizinin avasküler nekrozu olarak tanımlanabilir. Çocukların yeniden şekillenme kapasitesinin yüksek oluşu nedeniyle yetişkindeki benzerinden farklı seyreder. Hastalığın seyri boyunca her hastanın farklı değişkenlere maruz kalması nedeniyle, neredeyse hastalığın her hastada farklı şekilde seyretmesine neden olur. Bu durum standart tedavi protokollerinin geliştirilmesinin önünde engel teşkil eder. Tedavinin temel amacı femur başı küreselliğinin ve asetabuler uyumun hastalıktan en az düzeyde etkilenmesini sağlamaktır. Bu hedefi tutturmak için genel kabul edilen görüş femur başının asetabulum içinde tutulmasını sağlamak, bu sayede asetabulumun femur başını şekillendirmesini temin etmektir. Perthes hastalığında örtünme prensibinin uygulanması temel tedavi yöntemidir. Örtünme prensibi ya konservatif ya da cerrahi yöntemlerle sağlanabilir. Tedavisiz takip edilen hastaların çoğunda fonksiyonel olarak iyi sonuç bildirilse de hastalığın doğal seyri ve hastaya özgü prognostik etmenler göz önünde bulundurularak uygun müdahalenin yapılması gereklidir. Böylece erişkin dönemde dejeneratif koksartroz gelişiminden korunma sağlanabilir.

Anahtar sözcükler: Legg-Calve-Perthes hastalı̆ı̆; osteokondrozis; femur başının avasküler nekrozu
Although a century has passed after defining the Legg-CalvéPerthes disease, both its etiology had not been fully clarified and lack of consensus of the treatment methods lead the disease to remain still a mystery. Perthes disease can be defined as avascular necrosis of the femoral head epiphysis. Because of the high remodeling capacity of children, it is so different from its adult alike. During the course of the disease, due to presence of different factors affecting each patient, the disease progresses almost in a specific way in each patient. This situation causes difficulties in developing standard treatment protocols. The main aim of treatment is to maintain femoral head sphericity and acetabular congruency affected by the disease. To achieve these goals of treatment, commonly accepted concept is to maintain the femoral head within the acetabulum, thus to provide the shaping of the acetabulum and the femoral head. Containment principle is the key in treatment of Perthes disease. Containment principle can be achieved by either conservative or surgical methods. Although it is reported that most of the patients followed without treatment have good functional results; appropriate intervention is required considering natural course of the disease and patient specific prognostic factors. Thus, prevention of the development of degenerative coxarthrosis in adulthood can be achieved.

Key words: Legg-Calve-Perthes disease; osteochondrosis; avascular necrosis of femur head

erişkin dönem dejeneratif koksartroz gelişimini önlemektir. Baş deformasyonunun gelişmediği erken evredeki hastalarda başın küreselliğinin korunması amaçlanırken, baş deformasyonunun geliştiği geç evredeki hastalarda amaç kurtarıcı yöntemler ile tedavidir. ${ }^{[1]}$

\section{Epidemiyoloji}

Literatürde hastalığın yıllık insidansının bölgelere göre yüz binde 5,1 ile 21,1 arasında değiştiği bildirilse

Perthes hastalığı tedavisinde amaç, hastalığın seyri boyunca femur başı deformasyonuna engel olmak ve

- Iletişım adresi: Op. Dr. Timur Yıldııı, Metin Sabancı Baltalimanı Kemik Hastalıkları Eğitim ve Araştırma Hastanesi, Rumeli Hisarı Cad. No: 62 Baltalimanı, İstanbul Tel: 0212 - 3237075 e-posta: drtimur@hotmail.com

- Geliș tarihi: 3 Eylül $2014 \quad$ Kabul tarihi: 3 Eylül 2014 
de, Türkiye'deki görülme sıklığı ile ilgili kapsamlı bir çalışma yoktur. ${ }^{[2]}$ Perthes hastalığının teorik olarak fizisin radyolojik olarak görülebildiği 18 . aydan iskelet gelişimi tamamlanmasında kadar her yaşta görülebilmesi mümkün olsa da, sıklıkla 4-7 yaş arası çocuklarda görülür. Erkek çocuklar, kız çocuklarına göre 4-5 kat daha fazla etkilenirler. ${ }^{[3]}$ Perthes hastalarının \%10$15^{\prime}$ inde ilerleyen bir dönemde karşı kalça da tutulur. ${ }^{[4]}$

\section{Etiyoloji}

Perthes hastalığının etiyolojisini ortaya koymak amacıyla birçok çalışma yapılımıştır. Halen hastalığın etiyolojisi tam olarak bilinmemektedir; ancak hastalığın, yatkın çocukta multifaktöriyel zeminde geliştiğine inanılmaktadır. ${ }^{[5]}$ Hastalığın etiyolojisinde; femur başı arteryel veya venöz dolaşım bozuklukları, koagülasyon sistemi patolojileri, hiperaktivite, travma, düşük sosyoekonomik durum, pasif sigara içiciliği, düşük doğum ağırlığı, genetik ve iskelet yaşının geri olması gibi nedenler sıralanmıştır.

\section{Patogenez}

Waldenström, radyolojik olarak hastalığın kronolojik dönemlerini tanımlamıştır. Buna göre hastalık; başlangıç (nekroz), fragmantasyon, reossifikasyon (iyileşme) ve rezidüel dönemlerinden geçerek seyreder. Perthes hastalığında temel patoloji femur başı epifizinin iskemisidir. İskemi, tek ya da tekrarlayan ataklar şeklinde olabilir. Başlangıç döneminde (ortalama 6 ay) femur başının dolaşımı bozulur ve nekrotik kemik radyolojik olarak daha küçük ve radyoopak görünür. Fragmantasyon döneminde (ortalama 8 ay), avasküler nekrozun görüldüğü epifız kısmında nekrotik kemik osteoklastlar tarafından uzaklaştırılır. Bu nedenle zayıflayan epifiz bölümlerinde kollaps görülür ve parçalara ayrilır. Reossifikasyon döneminde (ortalama 51 ay), yeni kemik oluşumu örgümsü kemik ile başlar ve zamanla matür, lamellar kemiğe dönüşerek iyileşme tamamlanır. Rezidüel dönemde ise hasta, kalça ekleminde oluşan deformasyon ve sonuçları ile hayatını sürdürür. ${ }^{[1]}$

Femur başı epifizinde bahsedilen değişiklikler gelişirken kalça eklemi ve çevresindeki dokularda da bir dizi olay gelişir. Kalça ekleminde effüzyon görülür ve eklem kıkırdağı, sinoviyal doku ve ligamentum teres hipertrofiye olur. Kalça çevresi adale spazmı ile birlikte eklem içerisindeki bu değişiklikler, femur başının ilerleyici lateral subluksasyonuna neden olur. Asetabulum kenarının femur başına yaptı̆̆ bası ise epifizin lateral taşmasına neden olur. Daha sonra femur başı yeniden şekillense dahi bir miktar baş deformasyonu ve eklem uyumsuzluğu hayat boyu devam eder. ${ }^{[1,3]}$

\section{Sinıflama}

Perthes hastalığında kullanılan sınıflamaları erken ve geç dönem sonuçları değerlendiren sınıflamalar olarak ikiye ayırabiliriz.

\section{ERKEN DÖNEM SONUÇLARIN DEĞERLENDIRILMESi}

Hastalığın aktif döneminde epifizer tutulum miktarına göre oluşturulan sınıflamalar ile erken dönem sonuçları değerlendirilebilir.

\section{Herring sınıflaması (1992)}

Herring, femur başı epifizini koronal planda üç kolona ayırmış ve lateral kolon yüksekliğini değerlendirerek bir sınıflama yapmıştır (Tablo 1). Belirtilen lateral kolon, orta kolondan düzgün fragmantasyon hattı ile ayrı olarak izlenir ve epifizin \%15 ile \%30'luk bir kısmını oluşturur. Herring sınıflamasına göre Grup A en iyi prognoza sahipken Grup C en kötü prognoza sahiptir. Bu sınıflamanın güvenilirliğinin iyi düzeyde olduğunu gösteren yayınlar vardır. Günlük klinik uygulamada bu sınıflama kullanılmaktadır. ${ }^{[4]}$

\section{Catterall sınıflaması (1971)}

Catterall sınıflaması Perthes hastalığının modern anlamdaki ilk sınıflaması olarak bilinmektedir. Bu sınıflamada femur başı epifizi tutulum miktarına göre dört grupta sınıflandırmıştır (Tablo 2). Catterall

Tablo 1. Herring sınıflaması

\begin{tabular}{ll}
\hline GRUP A & Lateral kolon yüksek kaybı yok \\
GRUP B & Lateral kolon yüksekliği >\%50 \\
GRUP B/C & $\begin{array}{l}\text { 1. Ileri derecede dar (2-3 mm), \%50'den fazla } \\
\text { yüksekliğe sahip lateral kolon }\end{array}$ \\
& $\begin{array}{l}\text { 2. Ossifikasyonu az, \%50'den fazla yüksekliğe sahip } \\
\text { lateral kolon }\end{array}$ \\
& $\begin{array}{l}\text { 3. Santral kolona göre yüksekliği tam olarak \%50 } \\
\text { olan lateral kolon }\end{array}$ \\
GRUP C & Lateral kolon yüksekliği $<\% 50$
\end{tabular}

Tablo 2. Catterall sınıflaması

\begin{tabular}{ll}
\hline Grup 1 & $\begin{array}{l}\text { Epifız ön kısmında tutulum vardır, kollaps ve sekestrum } \\
\text { gözlenmez }\end{array}$ \\
Grup 2 & $\begin{array}{l}\text { Epifiz ön kısmındaki tutulum daha fazladır ve kollaps } \\
\text { ve sekestrum gözlenir }\end{array}$ \\
Grup 3 & Epifizin büyük kısmı sekestre olmuştur \\
Grup 4 & Epifizin tamamı tutulmuştur
\end{tabular}


sınıflamasında grup numarası arttıkça prognoz kötüleşir. Catterall sınıflamasında grupların ayrımını yapmak zordur ve gözlemciler arası değerlendirmede uyumsuzluk görülebilir. ${ }^{[6]}$

\section{Salter-Thompson sınıflaması (1984)}

Salter ve Thompson, subkondral kırık uzanım miktarının femur başı epifizi tutulumunu yansıttığını düşünerek iki gruplu bir sınıflama oluşturmuşlardır. Subkondral kırık miktarı \%50'nin altında ise Grup A, \%50'nin üzerinde ise Grup B olarak sınıflandırılır. Grup A'nın iyi prognoz, Grup B'nin ise kötü prognoz ile ilişkili olduğu bildirilmiştir. Ancak Perthes hastalarının yarısından daha az bir kısmında subkondral kırıklar radyolojik olarak görülebilir. ${ }^{[3]}$

\section{Conway sınıflaması (1993)}

Perthes hastalığının takip ve tedavisinde kullanılan röntgen tetkiki hastalığın erken dönemlerinde özgün bulgu vermemektedir. İskelet sintigrafisi ise kemik perfüzyonundaki değişiklikleri değerlendirmede yüksek duyarlılık ve özgüllüğe sahiptir. Bu nedenle, iskelet sintigrafisi ile röntgen tetkikine göre daha erken tanı konulabilir. Perthes hastalığında kanlanması bozulan epifizin yeniden kanlanması (revaskülarizasyon) iki şekilde gelişir. Birinci durumda, kan dolaşımının tromboz nedeni ile bozulduğu damarlarda trombolizis sonrası dolaşım yeniden sağlanabilir (rekanalizasyon). Dolaşım bu şekilde dakikalar veya haftalar gibi kısa sürede geri döner. Kan dolaşımının yeni damar oluşumu (neovaskülarizasyon) ile yeniden sağlanması ise ikinci durumdur. Bu durumda ise dolaşım aylar ya da yıllar gibi daha uzun sürede geri döner. Sintigrafik sınıflama bu iki revaskülarizasyon paterni üzerine kurulmuştur. Lateral kolonun sintigrafik olarak gözlenmesi rekanalizasyon sürecinin karakteristik bulgusudur ve iyi prognoz ile ilişkilidir. Sintigrafik olarak epifiz tabanında aktivite artışı (base filling) ve mantarlaşma (mushrooming) bulguları ise neovaskülerizasyon sürecinin karakteristik bulgularıdır. Bu bulguların gözlenmesi kötü prognoz ile ilişkilidir. Sintigrafik sınıflamada üç tip revaskülarizasyon paterni vardır. A paterni rekanalizasyonu ifade eder ve iyi prognoza sahiptir. B paterni neovaskülerizasyonu ifade eder ve kötü prognoza sahiptir. Nadir olarak gözlenen $C$ paterninde ise $A$ paterninden $B$ paternine dönüşüm gözlenir. Bu paternin gözlenmesi kollaps ve ekstrüzyonlar ile iyileşmenin göstergesidir. ${ }^{[7]}$

İskelet sintigrafisi, Perthes hastalığının erken tanısı ve prognozu hakkında bilgi verir. Bu nedenle hastalığın erken tanı ve tedavi seçiminde kullanılabilir. ${ }^{[7]}$ Ancak nihai sintigrafik paternin belirlenmesi için seri sintigrafi çekimlerinin getirdiği radyasyon maruziyeti ve tetkik maliyetleri, iskelet sintigrafisinin rutin kullanımında zorluklar olarak gösterilmektedir. ${ }^{[8,9]}$

\section{Manyetik rezonans (MR) görüntüleme}

Perthes hastalığının tanısında MR tetkiki yüksek duyarlılığa sahiptir. MR ile epifizer tutulum miktarı değerlendirilebilir. Ayrıca MR, femur başı kıkırdak şeklini, lateral ekstrüzyonu, lateral subluksasyonu ve labral eversiyonu değerlendirmek için iyi anatomik görüntüler verir. ${ }^{[10]}$

De Sanctis, fragmantasyon dönemindeki MR bulgularına göre prognostik sınıflama oluşturmuştur. ${ }^{[9]} \mathrm{Bu}$ sınıflamada, epifizer tutulum miktarı, lateral ekstrüzyon, fizisin tutulumu ve metafizer değişiklikler değerlendirilmiştir. Epifizer tutulumun $<\% 50$ olduğu Grup A'da prognoz iyiyken epifizer tutulumun $>\% 50$ olduğu Grup B'de kötüdür. Diğer parametreler ise alt grupların belirlenmesinde kullanılır. Bu sınıflamanın prognozu belirlemede ve tedavi seçiminde kullanılabileceği bildirilmiştir. ${ }^{[9]}$

\section{UZUN DÖNEM SONUÇLARIN DEĞERLENDIRILMESI}

Perthes hastalığı sonlandıktan sonra yapılacak değerlendirmeler hastanın dejeneratif koksartroz riskini belirlemede kullanılır.

\section{Stulberg sınıflaması}

Stulberg ve arkadaşları, Perthes hastalığı tanısı olan 156 hastanın 171 kalçasını en az 30 yılık takip süresinden sonra değerlendirmiş, hastaların femur başı ve asetabulum radyolojik görünümlerinin beş farklı gruba ayrılabileceğini gözlemlemişlerdir. Sınıf 1 'de kalça eklemi tamamen normaldir. Sınıf 2'de femur başı küreseldir ve normalden büyük bir baş, kısa femur boynu ya da sığ asetabulum görülebilir. Sınıf 3'te baş ovaldir ve baş, boyun, asetabulum değişiklikleri görülebilir. Sınıf 4'te femur başı ve asetabulum düzleşmiştir ve baş, boyun, asetabulum değişiklikleri görülebilir; kalça fleksiyon ve ekstansiyonu korunmuş olup rotasyon kaybı vardır. Sınıf 5'te ise femur başı düzleşmiştir, ancak femur boynu ve asetabulum normaldir. ${ }^{[11]}$

Stulberg hastalığın dejeneratif koksartroz ile ilişkisinin femur başı ve asetabulum eklem yüzeylerinin uyumu ile ilişkili olduğunu belirtilmiş ve üç tip uyumdan bahsedilmiştir (Tablo 3). ${ }^{[11]}$ Stulberg sınıflamasının güvenilirliği yüksektir ve günlük klinik uygulamada hastalığın sonuçlarının değerlendirilmesinde kullanılır. ${ }^{[4]}$ 
Tablo 3. Stulberg sınıflaması

\begin{tabular}{|c|c|c|}
\hline $\begin{array}{l}\text { Sinıf } 1 \\
\text { Sinıf } 2\end{array}$ & Sferik-uyumlu & Koksartroz gelişimi beklenmez \\
\hline $\begin{array}{l}\text { Sinıf } 3 \\
\text { Sinıf } 4\end{array}$ & Asferik-uyumlu & $\begin{array}{l}\text { Ileri yaşta hafif/orta koksartroz } \\
\text { gelişimi beklenir }\end{array}$ \\
\hline Sinıf 5 & Asferik-uyumsuz & $\begin{array}{l}<50 \text { yaş ciddi koksartroz gelişimi } \\
\text { beklenir }\end{array}$ \\
\hline
\end{tabular}

\section{Mose sınıflaması}

Bu sınıflamada, iyileşmiş olan başın küreselliğini değerlendirmek üzere yarıçapları $2 \mathrm{~mm}$ artarak büyüyen konsantrik halkalardan oluşan bir şablon kullanılır. Ön-arka ve yan grafilerde şablon ile başın küreselliği değerlendirilir. Buna göre baş, küresel, düzleşmiş ve düzensiz olarak üç gruba ayrılır. Ön-arka ve yan grafilerde femur başının yuvarlaklığı, belirlenen çemberdekine oranla $2 \mathrm{~mm}$ kadar sapma gösteriyorsa iyi, 2 mm'den fazla sapma gösteriyorsa sonuç kötü prognoz ile seyredeceği düşünülür. ${ }^{[12]}$

\section{DOĞAL SEYIR VE PROGNOSTIK FAKTÖRLER}

Perthes hastalığının doğal seyrinin ve prognostik faktörlerinin bilinmesi tedavi seçiminde önemli yere sahiptir. Perthes hastalığı sona erdikten sonra olguların az bir kısmında femur başı küreselliğini korur. Hastaların büyük kısmında oval ya da yassı bir femur başı mevcuttur. ${ }^{[13]}$ Perthes hastalığının prognozunu değerlendirmeye yönelik çeşitli faktörler bildirilmiştir. Kötü prognoz ile ilişkili kabul edilmiş major faktörleri; hastalığın geç başlangıçlı olması, femur başı tutulum miktarının fazla olması, femur başının asetabuler örtünmesinin azalması ve kalça hareket açıklığında azalma olarak sıralayabiliriz. ${ }^{[3]}$

Perthes hastalığında epifizer kollaps geliştikten sonra iskelet matüritesine kalan süre, deforme başın yeniden şekillenme potansiyelini belirler. Doğal olarak bu sürenin erken başlangıçlı hastalarda, geç başlangıçlı hastalardakinden daha fazla olacağı söylenebilir. Bu durum, küçük yaşta hastalığı geçirenlerin yeniden şekillenme potansiyelinin daha fazla olmasını sağlar.

Perthes hastaları, hastalığın başlangıç yaşına göre $<5$ yaş, $5-8$ yaş, 8-12 yaş ve $>12$ yaş olarak gruplandırılabilir. Beş yaş altı başlangıçlı Perthes hastalarının prognozu iyidir. ${ }^{[14]}$ On iki yaş üzeri grup ergen Perthes hastalığı olarak isimlendirilir ve erken başlangıçlı Perthes hastalığından farklı ve sıklıkla kötü prognozla seyreder.

Büyük çocuklarda gözlenen kötü prognozun diğer bir nedeni ise epifizer kemik-kıkırdak oranlarının küçük çocuklara göre daha fazla olmasıdır. Bu durum kollaps miktarının daha fazla olmasına neden olur. ${ }^{[3]}$

Yaş, önemli bir prognostik faktör olsa da tek belirleyici değildir. Epifizer tutulum miktarı da prognozu belirleyen diğer bir faktördür. Epifizer tutulum miktarının artması baş deformasyonunu arttırır. Altı yaşın altındaki hastaların prognozu \%80 iyi olsa da Herring Tip $B / C$ ve $C$ kalçaya sahip hastaların yarısı kötü prognoza sahiptir. ${ }^{[15]}$ Catterall Grup 1, Salter-Thompson Tip A ve lateral pillar Tip A hastaları gibi iyi prognoza sahiptir. Ancak Catterall Grup 3 ve 4, Salter-Thompson Tip $B$ ve lateral pillar Grup $C$ gibi kötü prognoza sahiptir. Catterall Grup 2, lateral pillar Grup B ve B/C hastalarının ise prognozlarını tahmin etmek zordur. ${ }^{[16]}$

Kız çocuklarının iskelet matüritesini tamamlamaları erkek çocuklara göre ortalama iki yaş daha erkendir. $\mathrm{Bu}$ da yeniden şekillenme potansiyelinin aynı yaştaki erkek çocuktan daha az olmasına yol açar. Kız çocukları erkek çocuklara göre daha az sıklıkta bu hastalığa yakalanmalarına rağmen, hastalandıklarında prognozları erkek çocuklarına göre daha kötüdür. ${ }^{[17]}$ Bilateral tutulumu olan hastalarda doğal seyir, tek taraf tutulumu olan hastalara göre daha kötüdür.. ${ }^{[3]}$ Catterall, kötü prognoz ile ilişkili klinik ve radyolojik 'risk altında kalça' kriterleri tanımlamıştır (Tablo 4). Bu bulguların Catterall Grup 2, 3 ve 4 kalçalarda varlığının kötü prognozla ilişkili olduğunu bildirmiştir. ${ }^{[3]}$ Stulberg sınıflamasına göre yapılacak değerlendirmeyle hastanın uzun dönem prognozu hakkında fikir sahibi olmak mümkündür. ${ }^{[11]}$

\section{DEĞERLENDIRME}

Yakınmaların başlama yaşı ve hastalığın süresi mutlaka değerlendirilmelidir. Hastalığın başlangıç yaşının tedavi seçiminde önemli yeri vardır. Perthes hastalığının erken dönemlerinde 'ağrısız aksama' tipik klinik bulgudur. İlerleyen dönemlerde ağrı; kalça, uyluk ya da diz ağıısı şeklinde karşımıza çıkabilir. Hastalar sıklıkla yakınları tarafından gözlenen aksamaları nedeni ile doktora getirilirler. ${ }^{[3]}$ Bu nedenle, ailesi tarafından yürüme

Tablo 4. Risk grupları

\begin{tabular}{ll}
\hline \multicolumn{2}{l}{ RISK ALTINDAKI BAŞ KRITERLERI } \\
\hline Radyolojik Bulgular & Klinik Bulgular \\
\hline Subluksasyon & Obezite \\
Metafizer kist & Progresif hareket kaybı \\
Lateral kalsifikasyon & Fleksiyon sırasında abduksiyona kaçış \\
Horizontal fizis & Adduksiyon kontraktürü \\
Gage bulgusu &
\end{tabular}


bozukluğu ya da diz ağrısı ile başvuran çocuklarda Perthes hastalığı akılda tutulmalıdır. Bu yakınmalar haftalar ya da aylar öncesinden başlamış olabilir. Fizik muayenede kalça eklem hareketlerinde azalmanın görülmesi, özellikle de abduksiyon ile iç rotasyon kısıtlılı̆̆

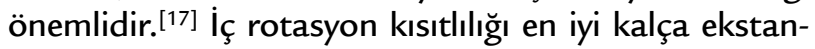
siyondayken tespit edilir. Bu, hasta yüzüstü yatarken dizler fleksiyona alınarak kalça rotasyonları değerlendirilebilir. Kalça hareket açıklığının ilerleyici azalması kötü prognoz bulgusudur.

\section{AYIRICI TANI}

Çocuklarda kalça ağrısı ve aksama ile giden hastalıklarda ayırıcı tanıya gidilmelidir. Çoğu zaman yaş, cinsiyet ve semptomların süresinin değerlendirilmesi, iyi bir fizik muayene ve radyolojik tetkik ile ayırıcı tanıya gidilebilir. Ayırıcı tanıda geçici sinovit, septik artrit, travmatik aseptik avasküler nekroz, hipotroidi, kondrolizis, tümörler, gelişimsel kalça displazisi tedavi sekelleri, kemik displazileri, Gaucher hastalığı, orak hücreli anemi, juvenil romatoid artrit akla gelmelidir.

\section{TEDAVi}

\section{Örtünme prensibi}

Perthes hastalığının tedavisi örtünme (containment) prensibine dayanır. Örtünme prensibinde, asetabulumun zayıflayan femur başını tamamen kapsaması ile femur başına etki eden kuvvetlerin eşit olarak dağılması amaçlanır. Ayrıca asetabulum, kalça hareketleri ile femur başının biyolojik şekillenmesine yardımcı olur ve sonuçta küresel, uyumlu bir kalça eklemi ile dejeneratif artritten korunma sağlanabilir. Her ne kadar kesin olarak tanımlanmamış olsa da, \%80'in üzerindeki örtünme miktarının femur başı lateral taşmayı ve kompresyonunu engellediği kabul edilir. ${ }^{[3,16]}$ Örtünme prensibi konservatif ya da cerrahi yöntemler ile sağlanabilir.

Herring, Perthes hastalığının tedavisi ile ilgili ileriye dönük çok merkezli çalışma yapmış ve lateral kolon sınıflaması ve yaşa göre tedavi ihtiyacı ile prognoz hakkında bir takım sonuçlar elde etmiştir. ${ }^{[5]}$ Bu sonuçları Tablo 5'teki gibi özetleyebiliriz.

\section{KONSERVATIF TEDAVi}

\section{Yükten kurtarma ve ortez kullanımı}

Yükten kurtarma tedavisi ile femur başı reossifikasyonuna kadar deformasyon gelişiminin engellenmesi amaçlanır. Değnek kullanımı, yatak istirahati, traksiyon, ortez ya da alçılama ile kalça ekleminin yükten kurtarılması mümkündür (Şekil 1). Brotherton, uzun süreli yatak istirahati ve alçı ile tedavi edilen hastalarda
Tablo 5. Herring tedavi algoritması

\begin{tabular}{|c|c|c|}
\hline Grup A & $\begin{array}{l}<8 \text { yaş } \\
>8 \text { yaş }\end{array}$ & Prognoz mükemmel, tedavi ihtiyacı yoktur \\
\hline & $<8$ yaş & Prognoz iyi, semptomatik tedavi gerektirir \\
\hline Grup B & >8yaş & $\begin{array}{l}\text { Femoral varizasyon ve Salter } \\
\text { osteotomisinden iyi sonuç alınır }\end{array}$ \\
\hline & $<8$ yaş & Prognoz iyi, semptomatik tedavi gerektirir \\
\hline Grup B/C & >8yaş & $\begin{array}{l}\text { Femoral varizasyon ve Salter } \\
\text { osteotomisinden iyi sonuç alınır }\end{array}$ \\
\hline Grup C & $\begin{array}{l}<8 \text { yaş } \\
>8 \text { yaş }\end{array}$ & $\begin{array}{l}\text { Yaştan ve tedaviden bağımsız olarak en kötü } \\
\text { prognoza sahiptir }\end{array}$ \\
\hline
\end{tabular}

\%88 iyi, \%10 orta ve \%2 kötü sonuç bildirilmiştir.[18] Rich ve Schoenecker A-çerçeve ortezi ile iyi sonuçlar bildirmişlerdir. ${ }^{[19]}$ Ancak ortez tedavisinin hastalığın doğal seyrini değiştirmede yeterli olmadığını bildiren çalışmalar da mevcuttur. ${ }^{[20,21]}$ Aksoy ve arkadaşları yaş, cinsiyet, takip süresi ve Herring sınıflamasına benzer olarak oluşturdukları ortez ile takip edilen 23 hastanın 23 kalçası ve ortez kullanılmadan takip edilen 25 hastanın 28 kalçasının uzun dönem sonuçlarını değerlendirmiş, buna göre, ortez kullanılan grup ile kullanılmayan grubun uzun dönem sonuçları arasında fark olmadığını bildirilmişlerdir. ${ }^{[21]}$ Ayrıca tedavi süresinin uzun sürmesi, hasta uyumunda zorluk, yatarak tedavi masraflarının fazla olması, hastalarda kas atrofisi, osteoporoz görülmesi gibi sakıncalar yükten kurtarma yönteminin uygulanmasında zorluk oluşturur. ${ }^{\left[{ }^{[3}\right.}$ Bu nedenlerle, Perthes hastalığının güncel tedavisinde ortez kullanım alanları giderek azalmaktadır. ${ }^{[22]}$

\section{CERRAHI TEDAVi}

Cerrahi yöntemler ile, revaskülarizasyon sürecine kadar femur başı küreselliğini korumak amacıyla örtünme sağlamak mümkündür. Böylece konservatif yöntemlere göre daha etkin ve uzun süreli bir örtünme elde edilebilir. Cerrahi örtünme tedavisi uygulanması için kalça hareketlerinin açık olması ve menteşeli abduksiyonun olmaması ön şartlardır. Cerrahi örtünme femoral ve asetabuler cerrahiler ile sağlanabilir. Ancak bunun hangi şekilde yapılması gerektiği ile ilgili ortak fikir yoktur.

Cerrahi örtünme prensibi ilk olarak Soeur tarafından femoral varizasyon osteotomisi uygulanarak gerçekleştirilmiştir. ${ }^{[23]}$ Daha sonra Salter, innominat osteotomi uygulamasıyla örtünme prensibine farklı bir bakış açısı kazandırmıştır. İleri derecede tutulumu olan Perthes hastalarında örtünme prensibinin sağlanması için femoral ve innominat osteotomilerin kombine kullanımı da yapılmıştır. ${ }^{[23]}$ 

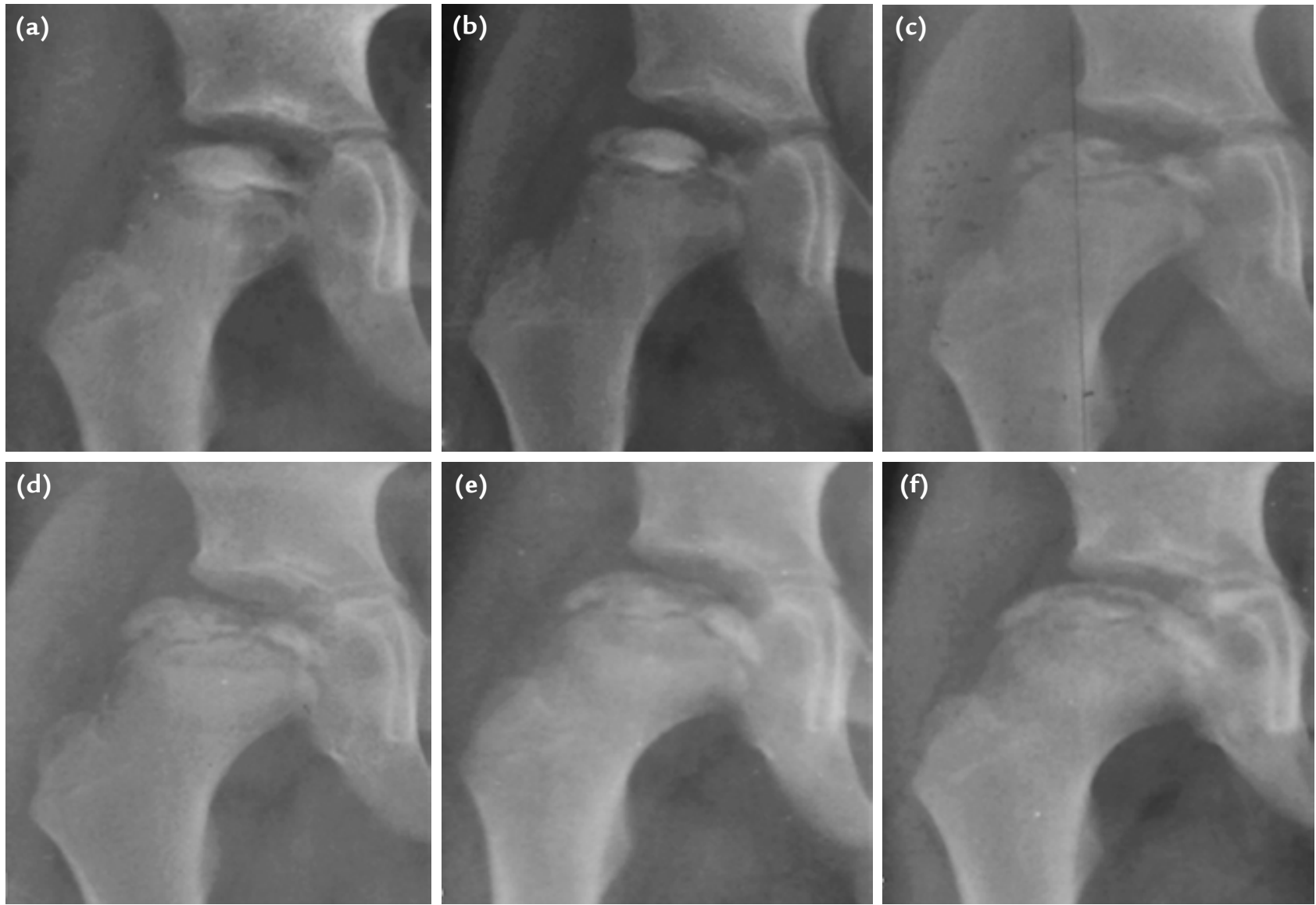

Şekil 1. a-f. Konservatif takip edilen altı yaşındaki erkek çocuğun takip kalça ön-arka grafileri: ilk başvuru (a); 3. ay (b); 6. ay (c); 10. ay (d); 1. yıl (e); 1,5 yıl (f).

\section{Varus osteotomisi}

Varus osteotomisi ile, asetabulum dışına taşma eğilimi olan femur başı lateral epifizinin asetabulum merkezine yönlenmesini amaçlanır. Femur başı, lateral epifizinin asetabulum tarafindan örtünmesi sonucu asetabulum kenarının deforme edici etkisinden korunur. Böylece asetabulum içerisinde kalan femur başının asetabulumun şekillendirici etkisinden yararlanılması sağlanır. Varus osteotomisi yapılması için kalça hareket açıklığının tam olması, abduksiyonda eklem uyumunun iyi ve asetabuler örtümün yeterli olması gereklidir. Hastalığın erken dönemlerinde uygulanan varus osteotomisinin iyi sonuçları bildirilmiştir. ${ }^{[23-25]}$

Varus osteotomisinin; uygulamasının kolay, sonuçlarının pelvik osteotomi kadar etkili olması ve eklem içi basınç artışına yol açmaması yöntemin avantajlarını oluşturur. Ayrıca avasküler nekroz döneminde uygulanması halinde hastaların üçte birinde fragmantasyon döneminin atlanması sayesinde hastalığın süresini kısalttığı gösterilmiştir.
Varus osteotomisinden sonra trokanterik bölgenin belirginleşmesi, abduktor topallama görülmesi, hastalık nedeni ile kısalık beklenen bacakta kısalığı artması, varus deformitesinin tamamen remodele olmaması, koksa brevanın artması, implant çıkarma için major ikinci bir cerrahinin gerekmesi dezavantajlar olarak gösterilebilir. Bu nedenle Perthes hastalığının erken dönemlerinde uygulanacak olan varus osteotomisinde $10^{\circ}$ ile $15^{\circ}$ 'lik varus oluşturulmasının yeterli olduğu bildirilmiştir. ${ }^{[26]}$

Ancak açık kama osteotomisi ile birlikte trokanterik epifizyodezin uygulanması durumlarında kısalık ve abduktor aksamada azalmanın olacağı düşünülmektedir. Varus osteotomisi tek başına uygulanabileceği gibi eklem uyumunu arttırmak ve ekstremite dizilimini iyileştirmek amacıyla derotasyon ve ekstansiyon etkileri sağlanacak şekilde de kullanılabilir.

\section{Pelvik osteotomi}

Perthes hastalı̆̆ında örtünme, pelvik tarafta uygulanan çeşitli yöntemlerle sağlanabilir. Seçilecek 
osteotomi tekniğine dair ortak fikir olmamakla birlikte tedavi sonuçları benzerdir.

Salter'a göre innominat osteotomi, kalça hareket açıklığı tam, küresel femur başına sahip, abduksiyonda uyumlu kalçalarda endikedir. Ayrıca Salter bu osteotomiyi, altı yaş üzerinde, başın \%50'sinden fazla tutulduğu subluksasyonu olan hastalarda kullanımını önermiştir. ${ }^{[3]}$ Salter osteotomisi ile tedavi edilen hastalarda iyi sonuçlar bildirilmiştir. ${ }^{[27,28]}$ Salter osteotomisinin kısalık oluşturmaması, abduktor aksamaya neden olmaması, kozmetik olarak daha iyi skar dokusu ile iyileşmesi avantajlarıdır. ${ }^{[3]}$ Ayrıca pelvik osteotomiler sonrasında femoral osteotomilere göre implant çıkarılması amacıyla ikinci bir major cerrahi gerekmez. Ancak pelvik osteotomilerin hastalı̆̆ın doğal seyrini değiştirdiğine dair kanıt bulunmamakla birlikte, aşırı örtünme sonrasında kalça sıkışma sendromuna neden olabileceği bildirilmiştir. Ayrıca, Salter osteotomisi femur başı üzerine etki eden kuvvetlerin artmasına neden olur.

\section{Kombine femoral ve Salter osteotomi}

Ciddi subluksasyonlu hastalar ile büyük çocuklarda Salter osteotomisi yeterli örtünme ve stabilite sağlayamayabilir. Bu durumda Salter osteotomisi ile femoral varus osteotomilerinin birlikte kullanımı mümkündür. ${ }^{[29,30]} \mathrm{Bu}$ hastalarda osteotomilerin tek başında kullanılmaları durumunda yetersiz örtünmenin görüldügü bildirilmiştir. Bu nedenle bu hastalarda femoral varus ile birlikte Salter osteotomisinin beraber uygulanması gerekebilir.

\section{Üçlü osteotomi}

Üçlü osteotomi asetabulumun ileri derecede hareketine olanak sağlar. Üçlü osteotomi ile, Salter ya da femoral osteotomilere göre daha fazla miktarda örtünme sağlanabilir.[31] Huang, shelf asetabuloplasti ile üçlü ostetotomiyi karşılaştıran çalışmada her iki grubun da tedaviden yarar gördüğünü bildirmişlerdir. Üç̧lü osteotominin teknik olarak daha zor olduğunu ve komplikasyonlarının daha fazla olduğunu ancak "shelf" asetabuloplasti grubunda daha az sayıda küresel femur başına sahip hastanın olduğunu bildirilmiştir. ${ }^{[32]}$ Üçlü osteotomide örtünmenin fazla yapılmasının sıkışma yapabileceği akılda tutulmalıdır. ${ }^{[33]}$

\section{Valgus osteotomisi}

Hastalığın aktif olduğu dönemde, yaştan bağımsız olarak örtünme prensibi uygulanamayan ya da iyileşme döneminden sonra ağrilı menteşeli abduksiyona sahip hastalarda, femur valgus osteotomisi tedavi seçeneği olarak kullanılabilir (Şekil 2). ${ }^{16]}$
Femur valgus osteotomisi ile eklem uyumunu arttırmak ve femoroasetabuler sıkışmayı azaltmak amaçlanır. Nötral veya abduksiyon grafilerinde kötü olan kalça eklem uyumunun adduksiyon grafisinde daha uyumlu hale gelmesi durumunda valgus osteotomisi kullanımı uygundur. Valgus osteotomisi ile, femoroasetabuler sıkışma yapan başın deforme alanı asetabulumdan uzaklaşır, yük taşıyan uyumlu yüzey miktarı artar, kollodiyafizer açı düzelerek kısalık düzelir, abduktor kas boyu uzar ve abduktor aksama azalır. Valgus osteotomisinin artikülotrokanterik mesafeyi arttırıcı etkisi de mevcuttur. ${ }^{[34]}$

\section{"Shelf" asetabuloplasti}

Örtünme prensibini sağlamak amacı ile Perthes hastalarında farklı tekniklerle "shelf" asetabuloplasti uygulanabilir. "Shelf” asetabuloplasti, femur başı lateral subluksasyonu, femur başı örtümünde yetersizlik ve menteşeli abduksiyon durumlarında kurtarıcıdır ya da hastalı̆̆ın erken dönemlerinde birincil örtüme tedavisi olarak kullanımı endikedir. ${ }^{[2]}$ "Shelf" asetabuloplasti tekniğinin diğer cerrahi yöntemlere göre olan avantajlarını; ileri düzeyde örtünme sağlayabilmesi ve bu sayede lateral subluksasyonun önlenebilmesi, femoral osteotomiyle karşılaştırıldığında kısalık oluşturmaması ve abduktor kuvvet kolunu bozmaması, pelvik osteotomilerle karşılaştırıldığında daha az cerrahi deneyim gerektirmesi ve daha az komplikasyon oranlarına sahip olması olarak sıralayabiliriz. ${ }^{[35-37]}$

\section{Artrodiastaz}

Perthes hastalığında femur başına etki eden mekanik kuvvetler, femur başı deformasyonuna neden olduğu gibi iskemi ataklarının oluşumunda da rol oynayabilir. Bu mekanik kuvvetlerin etkisini azaltmak amacıyla uygulanmış olan ortezlerin, aslında yükten koruma sağlamadıkları gösterilmiştir. ${ }^{[38]}$ Eksternal fiksatörler ile artrodiastaz yönteminin eklem çevresindeki anjiyogenezisi arttırdığı, yükten kurtardığı inancından yola çıkılarak tedavi yöntemi uygulanmıştır. Bu yöntemle, iyileşme fazına hızlı geçiş ve ciddi subluksasyonların redükte edilmesi sağlanabilmiştir. Ancak, komplikasyon oranlarının fazla olması, fiksatör çıkarılmasını takiben olguların yarısında örtünmenin kaybedilmesi ve sistemin hareketli bir yapıya sahip olmaması nedeniyle, rutin uygulama yerine sadece seçilmiş olgularda tercih edilmesi önerilir. ${ }^{[39]}$

\section{Cheilektomi}

Femoroasetabuler sıkışma durumunda, ekstrude parça eksize edilebilir. Ganz, güvenli çıkık yöntemi ile düşük avasküler nekroz riski ile cheilektomi 

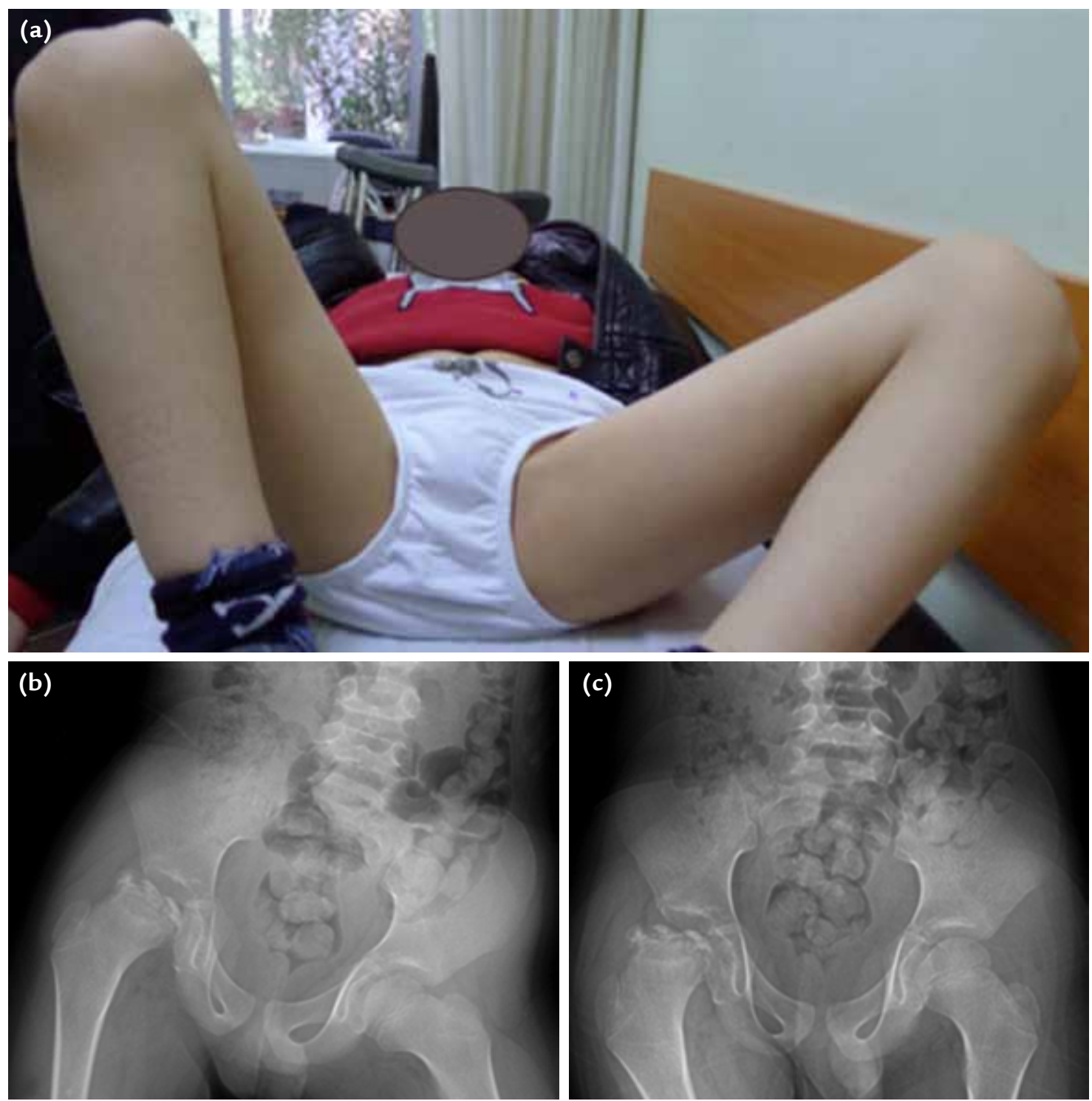

Şekil 2. a-c. Menteşeli abduksiyonu olan sekiz yaşında erkek çocukta abduksiyon kısıtlılığı (a), abduksiyon grafisi (b) ve adduksiyon uyum grafisi (c).

yapılabileceğini göstermiştir. ${ }^{[40,41]}$ Bu yöntem ile femur başına şekil vermenin daha iyi sonuca sahip olduğu bildirilmiştir. ${ }^{[42]}$

\section{Trokanterik epifizyodez}

Perthes hastalığında femur başı fizisinin erken kapanması ve trokanter majorun büyümeye devam etmesi sonucu, trokanterik aşırı büyüme olarak adlandırılan durum ortaya çıkar. Bu durum Trendelenburg topallamasına neden olur. Perthes hastalığında proksimal femur fizisinin erken kapanması öngörümü zor olduğundan, yedi yaş üzerindeki hastalarda örtünme cerrahisi sırasında profilaktik trokanterik epifizyodez önerilir. Femur varizasyon osteotomisi ile birlikte rutin olarak trokanterik epifizyodez uygulayan hekimler vardır. ${ }^{[1]}$

\section{Femur başı redüksiyon osteotomisi}

Perthes hastalığında koksa magna gelişmesi halinde, sıklıkla asetabulum kenarı ile temas eden santral bölgede kıkırdak dejenerasyonu gözlenir. Femur başı lateral üçte birlik kısımda ise, yük almaması nedeniyle, nispeten iyi bir kıkırdak tabakası olur. Femur başı mediyal kısmı ise, asetabulum içerisinde yer alması nedeniyle, benzer şekilde iyi kıkırdak tabakasına sahiptir. ${ }^{[43]}$ Ganz, 
bu değişiklikleri gözlemlemiş ve santral kısmın rezeksiyonu ile birlikte lateral kısmın vaskülaritesini koruyarak mediyal kolon ile osteosentezini uygulamıştır. ${ }^{[43]}$ Femur başı redüksiyon osteotomisi olarak adlandırdığı bu teknik ile küresel olmayan bir başı küresel hale getirmiştir. Böylece, Stulberg sınıflamasına göre hastalığın uzun dönem sonuçlarının iyileştirilmesi amaçlanır. Ancak, yeni uygulanan bir teknik olması nedeniyle, uzun dönem sonuçlarını bildiren çalışma henüz yoktur.

\section{PERTHES HASTALIĞINDA GELECEK TEDAVISi}

Femur başı mekanik fonksiyonlarının restorasyonu için nekrotik dokunun osteoklastlarca rezorbsiyonu gereklidir. Ancak bu rezorbsizyonun hızlı bir şekilde olması kollapsa neden olur. ${ }^{[20]}$ Hastalığın erken dönemlerinde kullanılan bifosfonatların osteoklastik kemik rezorbsiyonunu inhibe ederek femur başı kollapsını engellediği düşünülür. ${ }^{[3]}$ Femur başı iskemisi oluşturulan hayvan deneylerinde bifosfonat kullanımının femur başı sferisitesini koruduğu gösterilmiştir. ${ }^{[4]}$ Ancak klinik kanıtların halen yetersiz olması nedeniyle Perthes hastalığında kullanımı önerilmez. ${ }^{[45]}$

BMP'ler (bone morphogenic protein) ile bifosfonatların kemik onarımında sinerjik etkilerinin olduğu bilinir. ${ }^{[20]}$ Lokal ibandronat uygulaması ile birlikte BMP-2'nin uygulandığı bir hayvan deneyinde, kontrol grubuna göre femur başı deformitesinin daha az ve trabeküler kemik miktarının daha fazla olduğu gösterilmiştir. ${ }^{[46]}$

Perthes hastalarından yapılacak sinoviyal doku örneklemeleriyle, patogenezde rol oynayan inflamatuvar mediyatörler belirlenebilir. TNF- $\alpha$ benzeri bir mediyatör elde edilmesi halinde, juvenil romatoid artrit tedavisinde kullanılan infliximab benzeri tedaviler uygulanabilir. Enflamasyonun azalması, subluksasyon ve diğer deformasyon nedenlerinin azalmasına neden olabilir. ${ }^{[20]}$

\section{KAYNAKLAR}

1. Shah H. Perthes disease: evaluation and management. Orthop Clin North Am 2014;45(1):87-97. CrossRef

2. Herring J, editor. Tachdjian's Pediatric Orthopaedics: From the Texas Scottish Rite Hospital for Children. Saunders; 2013.

3. Wainwright AM, Catterall A. Legg-Calvé-Perthes Disease. In: Benson M, Fixsen J, Macnicol M, Parsch K, editors. Children's Orthopaedics and Fractures, 3rd ed. New York, NY: Springer; 2010. p.465-80.

4. Ömeroğlu H, Tümer Y. Çocuklarda kalçanın sık görülen hastalıkları. In: Çullu E, editor. Çocuk Ortopedisi. İstanbul: Bayçınar Tıbbi Yayıncılık; 2012. p.149-87.

5. Herring JA, Kim HT, Browne R. Legg-Calvé-Perthes disease. Part II: Prospective multicenter study of the effect of treatment on outcome. J Bone Joint Surg Am 2004;86-A(10):2121-34.

6. Catterall $A$. The natural history of Perthes' disease. J Bone Joint Surg Br 1971;53(1):37-53.
7. Conway J. A scintigraphic classification of Legg-CalvéPerthes disease. Semin Nucl Med 1993;23(4):274-95.

8. Cheng JC, Lam TP, Ng BK. Prognosis and prognostic factors of Legg-Calvé-Perthes disease. J Pediatr Orthop 2011;31(2 Suppl): S147-51. CrossRef

9. de Sanctis N, Rondinella F. Prognostic evaluation of LeggCalvé-Perthes disease by MRI. Part II. pathomorphogenesis and new classification. J Pediatr Orthop 2000;20(4):463-70.

10. Dimeglio A, Canavese F. Imaging in Legg-Calvé-Perthes disease. Orthop Clin North Am 2011;42(3):297-302. CrossRef

11. Stulberg SD, Cooperman DR, Wallensten R. The natural history of Legg-Calvé-Perthes disease. J Bone Joint Surg Am 1981;63(7):1095-108.

12. Joseph B. Prognostic factors and outcome measures in Perthes disease. Orthop Clin North Am 2011;42(3):303-15, $v$-vi. CrossRef

13. Herring JA, Kim HT, Browne R. Legg-Calvé-Perthes disease. Part I: Classification of radiographs with use of the modified lateral pillar and Stulberg classifications. J Bone Joint Surg Am 2004;86-A(10):2103-20.

14. Ippolito E, Tudisco C, Farsetti P. The long-term prognosis of unilateral Perthes' disease. J Bone Joint Surg Br 1987;69(2):243-50.

15. Rosenfeld SB, Herring JA, Chao JC. Legg-calve-perthes disease: a review of cases with onset before six years of age. J Bone Joint Surg Am 2007;89(12):2712-22.

16. Lovell WW, Weinstein SL, Flynn JM, editors. Lovell \& Winter's Pediatric Orthopaedics, 7th ed. Philadelphia: Wolters Kluwer Health/Lippincott Williams \& Wilkins; 2013.

17. Nguyen NA, Klein G, Dogbey G, McCourt JB, Mehlman $C T$. Operative versus nonoperative treatments for LeggCalvé-Perthes disease: a meta-analysis. J Pediatr Orthop 2012;32(7):697-705. CrossRef

18. Brotherton BJ, McKibbin B. Perthes' disease treated by prolonged recumbency and femoral head containment: a long-term appraisal. J Bone Joint Surg Br 1977;59(1):8-14.

19. Kamegaya M. Nonsurgical treatment of Legg-Calvé-Perthes disease. J Pediatr Orthop 2011;31(2 Suppl): S174-7. CrossRef

20. Little DG, Kim HK. Future biologic treatments for Perthes disease. Orthop Clin North Am 2011;42(3):423-7, viii. CrossRef

21. Aksoy MC, Caglar O, Yazici M, Alpaslan AM. Comparison between braced and non-braced Legg-Calvé-Perthes-disease patients: a radiological outcome study. J Pediatr Orthop B 2004;13(3):153-7.

22. Hardesty CK, Liu RW, Thompson GH. The role of bracing in Legg-Calve-Perthes disease. J Pediatr Orthop 2011;31(2 Suppl): S178-81. CrossRef

23. Wenger DR, Pandya NK. A brief history of Legg-CalvéPerthes disease. J Pediatr Orthop 2011;31(2 Suppl): S130-6. CrossRef

24. Lloyd-Roberts GC, Catterall A, Salamon PB. A controlled study of the indications for and the results of femoral osteotomy in Perthes' disease. J Bone Joint Surg Br 1976;58(1):31-6.

25. Coates CJ, Paterson JM, Woods KR, Catterall A, Fixsen JA. Femoral osteotomy in Perthes' disease. Results at maturity. J Bone Joint Surg Br 1990;72(4):581-5.

26. Kim H, Cunha A da, Browne R. How much varus is optimal with proximal femoral osteotomy to preserve the femoral head in Legg-Calvé-Perthes disease? J Bone Joint Surg Am 2011;93(4):341-7. 
27. Canale ST, D'Anca AF, Cotler JM, Snedden HE. Innominate osteotomy in Legg-Calvé-Perthes disease. J Bone Joint Surg Am 1972;54(1):25-40.

28. Paterson DC, Leitch JM, Foster BK. Results of innominate osteotomy in the treatment of Legg-Calvé-Perthes disease. Clin Orthop Relat Res 1991;(266):96-103.

29. Crutcher JP, Staheli LT. Combined osteotomy as a salvage procedure for severe Legg-Calvé-Perthes disease. J Pediatr Orthop 12(2):151-6.

30. Olney BW, Asher MA. Combined innominate and femoral osteotomy for the treatment of severe Legg-Calvé-Perthes disease. J Pediatr Orthop 5(6):645-51.

31. Price CT, Thompson GH, Wenger DR. Containment methods for treatment of Legg-Calvé-Perthes disease. Orthop Clin North Am 2011;42(3):329-40, vi. CrossRef

32. Huang MJ, Huang SC. Surgical treatment of severe perthes disease: comparison of triple osteotomy and shelf augmentation. J Formos Med Assoc 1999;98(3):183-9.

33. Hosalkar H, Munhoz da Cunha AL, Baldwin K, Ziebarth K, Wenger DR. Triple innominate osteotomy for Legg-CalvéPerthes disease in children: does the lateral coverage change with time? Clin Orthop Relat Res 2012;470(9):2402-10. CrossRef

34. Choi IH, Yoo WJ, Cho TJ, Moon HJ. The role of valgus osteotomy in LCPD. J Pediatr Orthop 2011;31(2 Suppl): S217-22. CrossRef

35. Freeman RT, Wainwright AM, Theologis TN, Benson MK. The outcome of patients with hinge abduction in severe Perthes disease treated by shelf acetabuloplasty. J Pediatr Orthop 2008;28(6):619-25. CrossRef

36. Rab GT. Theoretical study of subluxation in early Legg-CalvéPerthes disease. J Pediatr Orthop 25(6):728-33.

37. Pecquery R, Laville JM, Salmeron F. Legg-Calvé-Perthes disease treatment by augmentation acetabuloplasty. Orthop Traumatol Surg Res 2010;96(2):166-74. CrossRef
38. Martinez AG, Weinstein SL, Dietz FR. The weight-bearing abduction brace for the treatment of Legg-Perthes disease. J Bone Joint Surg Am 1992;74(1):12-21.

39. Kocaoglu M, Kilicoglu OI, Goksan SB, Cakmak M. Ilizarov fixator for treatment of Legg-Calvé-Perthes disease. J Pediatr Orthop B 1999;8(4):276-81.

40. Ganz R, Gill TJ, Gautier E, Ganz K, Krügel N, Berlemann U. Surgical dislocation of the adult hip a technique with full access to the femoral head and acetabulum without the risk of avascular necrosis. J Bone Joint Surg Br 2001;83(8):1119-24.

41. Lavigne M, Parvizi J, Beck M, Siebenrock KA, Ganz R, Leunig M. Anterior femoroacetabular impingement: part I. Techniques of joint preserving surgery. Clin Orthop Relat Res 2004;(418):61-6.

42. Rowe SM, Jung ST, Cheon SY, Choi J, Kang KD, Kim KH. Outcome of cheilectomy in Legg-Calvé-Perthes disease: minimum 25-year follow-up of five patients. J Pediatr Orthop 26(2):204-10.

43. Paley $D$. The treatment of femoral head deformity and coxa magna by the Ganz femoral head reduction osteotomy. Orthop Clin North Am 2011;42(3):389-99, viii. CrossRef

44. Kim HK, Randall TS, Bian H, Jenkins J, Garces A, Bauss F. Ibandronate for prevention of femoral head deformity after ischemic necrosis of the capital femoral epiphysis in immature pigs. J Bone Joint Surg Am 2005;87(3):550-7.

45. Young ML, Little DG, Kim HK. Evidence for using bisphosphonate to treat Legg-Calvé- Perthes Disease. Clin Orthop Relat Res 2012;470(9):2462-75. CrossRef

46. Vandermeer JS, Kamiya N, Aya-ay J, Garces A, Browne R, Kim HK. Local administration of ibandronate and bone morphogenetic protein-2 after ischemic osteonecrosis of the immature femoral head: a combined therapy that stimulates bone formation and decreases femoral head deformity. J Bone Joint Surg Am 2011;93(10):905-13. CrossRef 